DOI: 10.2478/atd-2021-0017

\title{
Difficult Situations in Educational Management
}

\author{
Daniel Lajčin*
}

Received: June 19, 2021; received in revised form: June 25, 2021; accepted: June 28, 2021

\begin{abstract}
:
Introduction: The scholarly paper focuses on addressing selected issues related to the forms of managers' behaviour in coping with difficult situations in managerial work.

Purpose: The aim is to enrich human knowledge in the field of coping with difficult situations in managerial work both at the methodological level and at the level of theory development in this area.

Methods: The most commonly used method was quantitative-qualitative content analysis of the text of various types of communicants in order to systematise, analyse and describe various phenomena and situations in educational management. We describe the objects and subjects they have a quantitatively and qualitatively differentiated essence and characteristics (manager's personality, demanding working environment, specific environment of class or school, processes at work, at school or during teaching, management style, workplace culture, etc.).

Conclusion: In terms of the specific application of the mentioned knowledge in managerial work, we can assume a positive impact on increasing the effectiveness of managerial work, in the context of which this can be used to increase the quality of selection of suitable people for managerial positions, education and training of managers, as well as prediction of possible risk factors in coping with difficult situations in managerial work.
\end{abstract}

Key words: managerially difficult situations, manager - educator, stress, risk factors, resilience.

\footnotetext{
* Daniel Lajčin, DTI University, Dubnica nad Váhom, Slovakia; lajcin@dti.sk
} 


\section{Acta Educationis Generalis \\ Volume 11, 2021, Issue 2}

\section{Introduction}

Difficult situations are part of the real existence of any person, and they affect all areas of life: family, school, sports, health, the environment and, naturally, work and working life (Barnová \& Gabrhelová, 2017). It is the field of work where the importance of the management of coping with difficult situations comes to the fore, as this coping is often associated with the effectiveness of managerial activities (Barnová \& Krásna, 2018) and the success of the educational organisation as a whole, thus affecting also other people. However, what are difficult situations, what determines that they are perceived as difficult, how they differ from "normal, not difficult" situations, where everywhere can we encounter such situations, what specifics do they have in the management of an educational organisation, how can they be handled, what all influences the coping with such situations, are the questions treated in a professional study.

The field of school management is one of the typical environments where the occurrence of difficult situations is not uncommon. Difficult situations can be perceived by school or educational institution managers as either problematic, crisis, conflict, complex, unpleasant, critical, stressful, or as an opportunity to demonstrate and apply own skills, as a challenge and starting point for career growth (Frankovský, Ištvániková, \& Štefko, 2009; Frankovský \& Lajčin, 2012). Some managers may avoid difficult situations, some may take them as a normal part of their work, or some may even deliberately seek them out. The difficulty of situations in managerial work needs therefore be interpreted in the context of the situational characteristics of performing this work and the dispositional traits of a particular manager. Choosing how to behave in these situations can have various consequences. Depending on how the individual handles these situations may mean self-empowering or self-threatening human behaviour (Fedáková, 2002).

Difficult situations in managerial work are represented not only by significant general and social phenomena, such as state interventions in the economy (Reinert, 1999), alliance building requirements (Kaulio \& Uppvall, 2009), but also by decisive milestones in the life of a manager (job loss, revocation from or appointment to a new position) or by the organisation's existence (bankruptcy, unexpected prospering), and ultimately are related to the problems and difficulties that managers face much more frequently, sometimes even on a daily basis (disagreements with co-workers, tense relations with superiors or subordinates, dismissal of employees, resolution of conflicts between subordinates, division of work tasks, remuneration of employees, etc.).

Research (Frankovský \& Ištvániková, 2008) dealing with the issue of coping with difficult situations in managerial work focused mainly on finding answers in at least three basic research contexts:

- Identifying, characterising and classifying situations perceived by managers as problematic, difficult, conflicting, complex, stressful, unpleasant, etc. 


\section{Acta Educationis Generalis \\ Volume 11, 2021, Issue 2}

- Analysis of managers' behaviour in addressing and coping with these situations, in order that using inductive taxonomy there could be created a general classification of managers' behaviour in addressing difficult situations.

- The third context includes analyses of the relations between the way of coping with difficult situations in managerial work and the dispositional features of the manager, or the situational conditions of the occurrence of a specific problem. In this focus, attention is mostly given to the dispositional traits of managers and the conditions of operation of the organisation.

The area of management is one of the typical environments in which the occurrence of difficult situations is not uncommon. The interest in researching the ways of managers' behaviour coping with difficult situations in their work is conditioned by the efforts to explain the general factors which, according to Výrost et al. (1995), relate to:

- Understanding life plans, personal perspective, career development.

- Information about the current state of motivational and emotional components of an individual's personality.

- Characterisation of ways and procedures of addressing and coping with problems.

In terms of practical use of knowledge acquired about coping with difficult situations in managerial work, according to Lajčin and Frankovský (2011) it is possible to assign to these general factors underlying the interest in these issues also specific applications in managerial practice related to:

- Recruitment for managerial positions, where these people inevitably encounter difficult situations.

- Training of managers holding these positions to effectively cope with difficult situations in the organisation's management (Pitt \& Sims, 1998; Talbot, 1997).

- Processing of procedures for addressing these situations within the organisation and their training at individual levels of management, e.g. for high-risk situations (Slaven \& Flin, 1994).

\section{Managerially difficult situations}

The growing interest among the professional and lay public in the issue of coping with difficult situations can be dated back to the early 1980s (Folkman \& Lazarus, 1980; Folkman et al., 1986; Lazarus, 1981; Lazarus \& Folkman, 1987; Carver et al., 1989; Amirkhan, 1990; Nurmi, Toivonen, Salmela-Aro, \& Eronen, 1996; Folkman \& Moskowitz, 2004), and today this field of knowledge still enjoys attention (Mcnaughton-Cassill, 2015; McCarthy, Erdogan, \& Bauer, 2019; Modranský, Bočková, \& Hanák, 2020; Barlette, Jaouen, \& Baillette, 2021). The presented interest is a reflection of the general rapid dynamics in people's lives (need for mechanisms of democratic resolution of social issues, increasing number of difficult situations in life, e.g. Covid-19, where a manager 
must analyse, compare and evaluate assumptions, strengths and weaknesses, opportunities and risks of online education at schools in terms of managerial competencies of schools' management or educational management, ensuring the quality of online education, educational needs of students and further education of teachers of different types of schools as a prerequisite for creating innovations in the virtual environment of the new educational reality, including the rising interest in questions as to how effectively address these situations, what is their impact on the mental health, health and well-being of a person, addressing the issues of quality of life, etc.), as well as of specific requirements of social practice (new approach and development of managerial activities, effective functioning of an organisation, the need to adopt unpopular measures, time stress in decision making, conflicts in the workplace, team building, etc.).

If a person gets into a difficult situation, the focus of that person's attention is on solving the situation, considering possible procedures, obtaining the necessary information, seeking help, finding escape options, etc. Perhaps this is the reason why answering the question and explaining what a difficult situation is, how to identify it, which situations people evaluate as stressful, problematic, conflicting, complex, unpleasant, recedes into the background, is not prioritised, while, paradoxically, the definition of difficult situation receives less attention than the questions concentrating on how one handles such situations, what forms of behaviour one chooses, how one resolves them.

In terms of the needs of an organisation, e.g. school, but also a specific manager, this is logical. For the representatives of all these positions, the decisive fact remains as to how the manager addresses the given situation, how he/she behaves in it, how he/she handles it, what is the efficiency of his/her conduct. This fact consequently guides the attention of most researchers in the direction towards behaviour analysis and its predictors related to the manager's traits or the characteristics of the difficult situation. All this happens while the question of what a difficult situation is, or what kind of situation a person perceives as difficult is crucial, both in terms of its identification and in terms of its solution (Frankovský, 2001; Madsen, \& Petermans, 2020). The answer to this question is also crucial in terms of the managers' training to deal with different types of difficult situations, as well as in terms of developing specific procedures within an organisation to address certain difficult situations.

The perception of the degree of difficulty of the situation is different on the individual level. It is obvious that, for instance, changes in the national or school curriculum or the transition to online education is simply ordinary work for some managers - something that they do not perceive as stress, a burden, or an unpleasant situation. On the other hand, other managers may perceive the same situation as difficult, stressful, unpleasant. Coping with this situation requires from them maximum commitment, self-control and personal coping with this situation. Nonetheless, the situation's difficulty as such can be viewed as a threat, fear of failure, on the one hand, but can also be perceived as a challenge, 
an incentive to embark on something new, to prove one's own qualities, to assert oneself, on the other hand. It is clear from these examples that the very effect of the level of difficulty and its subjective assessment must be interpreted both in the context of situational characteristics in which situation coping takes place, and in the context of dispositional traits of a particular manager who is an actor in such coping (Krásna, Geršicová, \& Tamášová, 2016; Yip Goldman, \& Martin, 2021).

\section{Classification of difficult situations}

The classification of difficult situations and its subsequent typology, with rare exceptions, presuppose the multidimensional nature of the systematic classification of situations by defined criteria. As a result, it is possible to classify a specific difficult situation into a certain generalised category (Holmes \& Rahe, as cited by Reese \& Smyer, 1983; Pujol-Cols \& Lazzaro-Salazar, 2020). It should be noted that this highly generalised definition of difficult situations does not take into account either the individual specifics of managers, nor the specifics of individual organisations, nor the specifics of individual management activities and, ultimately, neither does it take into consideration the specifics of a particular difficult situation. This approach does not allow to effectively define predictors of behaviour in a difficult situation. From a practical point of view, the one-dimensional approach is not optimal at the level of diagnosing difficult situations, or the management of their coping, and therefore little attention is paid to this aspect, both in research and practice. From a theoretical and methodological point of view, regarding the concept of onedimensional understanding of the difficulty of situation it would be possible to consider a two-dimensional approach, in which difficulty and non-difficulty would be defined as separate dimensions. In this context, it is possible to think about the types of situations that are evaluated in the dimension of their difficulty (from the least difficult to the most difficult) and about the types of situations that are evaluated in the dimension of their non-difficulty (from the least non-complex to the most non-complex). Using this approach should make distinction between the levels of minimum and maximum non-difficulty and minimum and maximum difficulty. The mentioned specification would make it possible, for example, to analyse the ties between these two independent dimensions and the dispositional traits and situational characteristics entering into coping with a difficult situation.

In contrast to one-dimensional thinking about the classification of difficult situations, Reese and Smyer (1983) propose, in the focusing on multidimensional categorisation of situations, two essential dimensions of taxonomy and classification of difficult situations as life events:

- Type of life event;

- Context of life event. 
Based on the first dimension - type of life event, the authors propose to distinguish the following four levels of this dimension, which allow to specify the following types of life events: 1. type biological, 2. individual psychological, 3. cultural - sociological, 4. physical.

The second dimension makes it possible to distinguish the following fourteen contexts of life events, which specify the contents of the specified types of life events, as defined within the first dimension: Family, Love and marriage, Parenting, Housing, Health, I, Public, Friends, Social relations, Money, School, Work, Law, Other ....

In relation to the above classification, we can cite an example of a difficult situation - promotion to a higher managerial position or job loss. It can be classified as an event of individual-psychological type and as the context of work. In a similar system - context framework, we would probably characterise most of the difficult situations associated with the management of an organisation. Problems with a superior would thus be represented by an event of an individual-psychological type and the context of work.

When evaluating the proposed classification of life events, it is not always possible to clearly assign a specific situation to a specific type and context of events.

Baumgartner and Hadušovská (1997) write that the study of situations and the attention paid to this area has had a long tradition and research has been carried out mainly in the field of psychology and sociology. In this focus, we encounter a number of older research concepts. According to Krahé (1990) and Pujol-Cols and Lazzaro-Salazar (2020), approaches to the study of subjective construction of the meaning of situations can be classified into three concepts:

- Social episodes - research oriented at revealing the dimensions of cognitive representations of situations that specify the process of recognising these situations.

- Situational prototypes - research oriented at the categorisation of social stimuli in relation to situational characteristics.

- Cognitive scenarios - research oriented at the relationship between information about situations and their cognitive processing.

Výrost (1997) proposed a classification of difficult situations associated with the attempt to conceptually clarify the essential categories related to the issue of coping on the basis of an analysis of several researches in this area of knowledge. The specification of situation types is based on the distinction of conditions (antecedents) and responses (consequences) to these conditions. In terms of situations that are perceived as difficult, the author described three larger groupings that can be characterised as stressful situations, life events and difficult life situations. Likewise, three groupings were characterised in terms of consequences, i.e. responses to these situations. In this case, we consider coping, life skills and behaviour strategies. Based on these groupings on the antecedents 
and consequences side, the links between the types of situations and the responses to these situations were defined (Figure 1).

\begin{tabular}{|lll|}
\hline STRESSFUL SITUATIONS & $\Rightarrow \Rightarrow \Rightarrow \Rightarrow$ & COPING \\
LIFE EVENTS & $\Rightarrow \Rightarrow \Rightarrow \Rightarrow$ & LIFE SKILLS \\
DIFFICULT LIVING SITUATIONS & $\Rightarrow \Rightarrow \Rightarrow \Rightarrow$ & BEHAVIOUR STRATEGIES \\
\hline
\end{tabular}

Figure 1. Mutual relations between selected antecedents and consequences (Výrost, 1997).

From the above scheme it is possible to specify that research in stress situation aligns with analyses - coping, life events align with the research of life skills, and difficult life situations align with the research of behaviour strategies.

In contrast to the presented scheme of cause-and-effect relationships, instead of the designation 'difficult life situations', in this study we use managerially difficult situations due to a more significant distinction of difficult situations and life events, or of stressful situations in terms of common, everyday occurrence. At the same time, where consequences are concerned, we use the term coping mainly due to a broader scope of possible reactions to the emerging difficult situations.

Of these three types of difficult situations, research at the level of stressful situations, as extraordinary events of a general threat to a person, often associated with a threat to life, has enjoyed the longest tradition.

The concept 'stress' keeps appearing and has received increased attention since the 1940s in connection with the period of World War II and the addressing of the issue of war neuroses. World War II was a great tragedy and a disaster for humanity. However, it was also a period when attention began to be paid to the impact of surviving tragedies, life-threatening situations on the human mental state. According to Bratská (2001), the first monograph devoted to the issue of stress by Gringer and Spiegel - Men under Stress - was published in this period, specifically in 1945.

Selye $(1956,1966)$, as perhaps the best-known author in relation to the study of stress, focused on the research into the influence of stressors on the course of physiological processes and their impact on human mental health. In this case, the cause (antecedent) was a stressful situation, which causes a complex of reactions called GAS (General Adaptation Syndrome). In the original concept, stressful situations were characterised as extreme, critical, frequently, as has already been mentioned, on the verge of life-threatening. However, the stress antecedents have been expanded in the current understanding of stress to a much broader complex of situations that affect the body. In this focus, which, in addition to the physiological context, also drew attention to the psychological context, it is necessary to mention the contribution of Lazarus and Folkman 
(1984), who emphasised the subjectivity of assessing the degree of threat caused by a given situation.

In relation to the specification of the concept 'stress', Daniel (1997) proposes a distinction between the concept 'burden' and 'stress'. In this context, 'burden' is associated with common situations, or less difficult, and 'stress' with highly difficult, critical situations. The degree of difficulty though must be interpreted not only from the aspect of its amount in the short term, but also from the aspect of its long-term effect. Already Lazarus (1993) pointed out that in everyday life many conditions (marriage, love, illness, job, school exam, investment decision, type of production, choice of suppliers, insolvency, conflicts in the workplace) can produce effects comparable to those examined in combat conditions, especially if they act for a long time and repeatedly. Birkner (2010), Herrero, Egbu and Fong (2018) also point out the fact that the stress level is related not only to extremely difficult life situations, but also to situations that are basically not so demanding, but are mildly burdensome and last a long period of time, i.e. situations that are not stressful in intensity but in duration.

At present, a much broader discussion, in terms of topics, on the dispositional, situational and interactive processes of learning of psychological phenomena, on the influence of cognitive, motivational and emotional factors on these processes is reflected in the individual approaches to the definition of stress and the proposals for its research (Frankovský, 2003).

In relation to the above ideas, it is possible to divide the encounter with a managerially difficult situation in the managerial work and the reaction to such encounter into the following stages:

- Primary evaluation of the situation. Does this situation threaten me, what is its level of difficulty?

- Secondary evaluation of the situation. I will cope to solve this, what should I do, what procedure to choose (Baštecká \& Goldman, 2001).

An important characteristic of the primary and secondary evaluation of the situation, as mentioned by Baštecká and Goldman (2001), is the aspect of the subjectivity of this process. When assessing the degree of threat, difficulty, but also when assessing the likelihood of coping with the situation, as well as the choice of procedure, a subjective comparison with own schemes of threat, difficulty, and solution procedures comes to the fore.

The importance of subjective assessment of a difficult situation is also emphasised in the characterisation of stressful situations by Atkinson et al. (1995). The author states that stressful events are most often individually evaluated as uncontrollable, unpredictable, at the limit of human abilities. The degree of difficulty of the situation is therefore the result of subjective perception and evaluation of several criteria of the situation faced by the person. These criteria can be specified as follows:

- inability to influence the situation;

- inability to predict the emergence of a stressful situation; 


\section{Acta Educationis Generalis \\ Volume 11, 2021, Issue 2}

- excessive and disproportionate claims;

- life change that requires significant adaptation;

- subjectively unsolvable internal conflicts.

\subsection{Taxonomy, context and categorisation of situations}

The taxonomy of situations based on the degree of difficulty, which, unlike previous taxonomies, is derived from the results of the effect of these situations on people, was developed by Mikšík (1991). The degree of burden that results from the difficulty of the situation in this concept ranges across the full scale of continuum - from the optimal burden stimulating mental development through to the extreme burden causing mental breakdown and leading to disintegration of personality. Difficult situations are then classified in this taxonomy as:

- Performance-intensive situations - in an extreme form they lead to the exhaustion of physical or mental strength, it is impossible to cope with them indefinitely.

- Problematic situations - they require a new solution, heuristic procedures, a new way of working, they can lead to an inability to solve the problem, to a loss of self-confidence.

- Situations of frustration - an insurmountable obstacle appears between the individual and the goal of his activity, they can cause syndromes of frustration or deprivation.

- Conflict situations - they lead to disintegration of decision-making processes, they are caused by the presence of several equivalent solution alternatives, or interpersonal conflicts.

- Stressogenic situations - they lead to the disintegration of mental structures; they are associated with situations threatening the existence of an individual.

A multidimensional classification of difficult situations was described by Výrost et al. (1995), Bolfíková (1997), Baumgartner and Hadušovká (1997). The above classification of difficult situations was performed on the basis of an inductive approach, which took place in several consecutive stages.

The mentioned procedure (Bolfiková, 1997) produced, with the aid of an openended question, a description of 5 life situations, which the respondents experienced as the most demanding in their lives. At the same time, respondents ranked these situations according to their level of difficulty. The performed content analysis of descriptions of difficult situations made it possible to define 5 criteria of the specification and classification of these situations: a) Sociocultural level; b) Level of problem; c) Level of time; d) Level of social closeness; e) Level of fact and survival.

The criteria that proved to be the most effective for the final form of the taxonomy of difficult situations: socio-cultural level and level of social closeness.

The processing of the obtained empirical material in terms of the first criterion (socio-cultural level) made it possible to specify eight contexts of situations, 


\section{Acta Educationis Generalis \\ Volume 11, 2021, Issue 2}

which were represented by the following areas: Health; Partnerships; Family; Self-reflection; Study and school; Job and workplace; Money, material values; Morality, existential issues, social norms.

The analysis in the social closeness level made it possible to categorise the situations into four types, the common denominator of which was social closeness: I; Closest person to me; My acquaintances; Society, state, world.

The results of this research provided a basic insight into the possible categorisation of situations and thus prepared material for further analysis. At the same time, though, they provided information on the frequency of emergence of individual types of difficult situations.

The above procedure of classification of difficult situations was continued in the works by Výrost et al. (1995), Baumgartner and Hadušovská (1997), who, on the basis of subjective perception of affinity and evaluation of difficulty of specific situation defined, by combination of 8 contexts of situations and 4 possible subjects - actors of situations, 64 model difficult situations (each combination was represented by two situations). By applying mathematical-statistical procedures (factor analysis, multidimensional scaling and Q-sort) they were classified using two decisive factors - the actor in the difficult situation (the subject of the situation - the one to whom it happened) and the context of this situation (what happened, what is the content of the situation), the following challenging situations:

- In the area of the closest interpersonal relationships of the individual (partner, friend and family relationships).

- In the area of broader interpersonal relationships of the individual (work, education and material security).

- Associated with immediate danger to life (illness, injury, death).

- In the area of existential and moral problems (meaning of life).

The difficult situations that can occur in the organisation's management are characterised by Copper and Marshall (1978) on the basis of six areas of stress in the work context as:

- Internal work environment - in this area it is mainly the conditions and manifestations directly related to the performance of work activities such as mental or physical overload, work environment, work rhythm, level of risk factors, flexibility, etc.

- Organisation's environment - these are the factors of work organisation, such as precise definition of work activity, degree of responsibility, etc.

- Social environment - attention is focused mainly on social relations with coworkers, superiors and subordinates. These relationships are considered to be an important mediator of the effect of stress factors, which can correct the mentioned effect in both a positive or negative direction.

- Career prospect - here can be included questions related to professional and career growth and advancement (reassignment to a higher, lower position, clear conditions for career growth, opportunities for advancement, etc.). 


\section{Acta Educationis Generalis \\ Volume 11, 2021, Issue 2}

- Organisational culture - these are factors related to the overall culture of life of the organisation, the level of communication, the form of employee management, problem solving, employee care.

- Work and family life - here can be included activities related to the harmonisation of the requirements that employment and the family place on a person. In particular, addressing conflict situations in which it is necessary to meet the work requirements at the expense of the family.

According to Oravcová (2004), and Ronginska and Doliński (2020) difficult situations in managerial work can be specified not only on the basis of stressful conditions, but also in contexts that are not uncommon in everyday life and are based on:

- Time pressure - mostly associated with the performance of precisely timed tasks.

- Excessive quantity of tasks.

- Excessive variety of tasks.

- Chaotic organisation of work.

- Stereotypical and boring nature of work.

The relatively separate and specific area of managerially difficult situations in the management of an organisation is defined by the issue of organisational change and the related management of coping with this change and its consequences. In this context, Judge, Thoresen and Pucik (1999) examined managerial coping with organisational change in terms of the seven dispositional traits of managers (locus of control, generalised self-efficacy, self-esteem, positive affectivity, openness to experience, tolerance for ambiguity, and risk aversion). Based on these characteristics, they extracted two factors: positive self-concept and risk tolerance, which are significantly related to the management of coping with organisational change. At the same time, these authors pointed out the importance of the context in which the organisational change takes place (job position, salary conditions, job satisfaction, management of the organisation, career growth, etc.). The analyses of these authors confirmed the position of mediators of the contextual conditions through which the extracted factors act on the coping process.

Beech and Caims (2001) and Herrero, Egbu, and Fong (2018) also highlighted the importance of coping processes as active procedures aimed at success in implementing organisational change. At the same time, they also highlighted cases in which coping was understood more as a passive, defensive reaction to change.

Another possible approach to the specification and typology of difficult situations in the organisation's management is to differentiate them into individual and collectively difficult situations (Muhonen \& Torkelson, 2008).

Another view of the occurrence of difficult situations in the work of a manager, in terms of rather qualitative characteristics, is presented by Urban (2008). The author works from the assumption that an essential part of managerial work is 


\section{Acta Educationis Generalis \\ Volume 11, 2021, Issue 2}

not so much the creation of long-term visions and strategies, but rather the solution of minor human problems, issues of motivation, improving employees' skills. Based on the above, the author suggested 10 areas of difficult situations that managers must cope with. In this way he distinguishes the following areas of difficult situations:

- Self-management.

- Transition from a performance function to a managerial function.

- Managing motivation and persuasion.

- Control management and delivery of adverse messages.

- Management of difficult-to-cope-with co-workers (subordinates and superiors).

- Overcoming conflicts and stress.

- Change management.

- Transition from management to leadership and coaching.

- Creating and managing an effective team.

- Management in an international environment.

Naturally, it is also possible to discuss other areas of occurrence of difficult situations in managerial work. However, as the author notes, the number of situations defined in this way is not decisive. The aim of the specification of the presented structure of difficult situations was to cover the essential areas of selfmanagement, through people management to the international, cultural context of management.

A specific view of the definition of managerially difficult situations in management is represented by the currently very frequent approach to the study of work-family conflict as a clash of two responsibilities in relation to the family and in relation to employment. Multiple studies (Aluko, 2009; Lorincová \& Birknerová, 2019) describe this type of difficult situation as highly stressful.

Work-life balance is one of the main topics on the European Union's social policy agenda (Sklenár, Frankovský et al., 2007; Ika, Couillard, \& Garon 2021). In the real life of organisations, this topic is reflected in the implementation of a family-friendly strategy to cope with this difficult situation in the management of organisations.

\section{Conclusion}

The mentioned procedures for finding the structure of managerially difficult situations, generally also directly in management, represent typical approaches to this issue that can be found in the literature. They are characterised by a multidimensional approach to defining the structure of these situations and an empirical-inductive process of identifying individual elements of the structure of difficult situations. The theoretical-deductive procedure of defining the structure of difficult situations can be found more rarely. From the opinions of individual 


\section{Acta Educationis Generalis \\ Volume 11, 2021, Issue 2}

authors presented above, we could assign to this approach the classification of the 10 areas of situations proposed by Urban (2008).

The presented taxonomies of difficult situations in general, as well as in managerial work, testify to the fact that there are many such approaches, proposals, and concepts. In addition to the above-listed characteristics, in the varied mosaic of these approaches we can generalise taxonomies oriented more procedurally (Urban, 2008) or contextually (Střelka, 2008; Rost, Sonnenmoser, $\&$ Renzel, 2019). We want to draw attention to and emphasise the importance of the factor of subjective evaluation of a difficult situation, which is related to both the dispositional attributes of the manager and the conditions of a specific situation.

Encounters with difficult situations, the way they are addressed and the residuals of these processes can significantly affect the quality of manager's life, existence, mental and physical health. As a result, at present more and more attention is focused on the issues of perception, experience and effective solution of difficult situations in the management of an educational institution (or company), though neither do the conditions causing these situations and underlying their solution escape attention.

The search for effective ways of coping with difficult situations in managerial work is a process that must therefore be based on an interdisciplinary view of the issue.

\section{Acknowledgement}

The contribution was created within the solution of the scientific project IGA 007DTI University/2020: Managerial competences and innovations in current educational practice. at DTI University in Dubnica nad Váhom, Slovakia.

\section{References}

Aluko, Y. A. (2009). Work-family conflict and coping strategies adopted by women in academia. Gender \& Behaviour, l7(1), 2095-2122.

Amirkhan, J. H. (1990). A factor analytically derived measure of coping: The coping strategy indicator. Journal of Personality and Social Psychology, 59, 1066-1074.

Atkinson, R. L., Atkinson, R. C., Smith, E. E., \& Bem, D. J. (1995). Psychologie. Praha: Victoria Publish.

Barlette, Y., Jaouen, A., \& Baillette, P. (2021). Bring Your Own Device (BYOD) as reversed IT adoption: Insights into managers' coping strategies. International Journal of Information Management, 56. https://doi.org/10.1016/j.ijinfomgt.2020.102212

Barnová, S., \& Gabrhelová, G. (2017). Resilience in Schools. Karlsruhe: Ste-Con.

Barnová, S, \& Krásna, S. (2018). Managers and workplace stress. In Š. Majtán et al., Aktuálne problémy podnikovej sféry (pp. 51-56). Bratislava: EKONÓM.

Baštecká, B., \& Goldman, P. (2001). Základy klinické psychologie. Praha: Portál.

Baumgartner, F., \& Hadušovká, S. (1997). Dimenzie náročných životných situácií a možnosti ich klasifikácie. In L. Lovaš, \& J. Výrost (Eds.), Stratégie správania v náročných životných situáciách (pp. 16-37). Košice: Spoločenskovedný ústav SAV. 


\section{Acta Educationis Generalis \\ Volume 11, 2021, Issue 2}

Beech, N., \& Caims, G. (2001). Coping with change: The contribution of postdichotomous ontologies. Human Relations, 54(10), 1303-1324.

Birknerová, Z., \& Čigarská, B. N. (2021). Analysis of the links between burnout syndrome and coping strategies in trade managers. International Journal of Organizational Leadership, $10(2), 140-154$.

Birknerová, Z. (2010). Stres a jeho zvládanie riaditel'mi škôl. Manažment školy v praxi (pp. 2126). Bratislava: IURA EDITION.

Bolfiková, E. (1997). Náročné životné situácie - možnosti empirickej klasifikácie. In L. Lovaš, \& J. Výrost (Eds.), Stratégie správania v náročných životných situáciách (pp. 38-46). Košice: Spoločenskovedný ústav SAV.

Bratská, M. (2001). Zisky a straty v zátažových situáciách alebo príprava na život. Bratislava: Práca.

Carver, C., S., Scheier, M., F., \& Weintraub, J., K. (1989). Assessing coping strategies: A theoretically based approach. Journal of Personality and Social Psychology, 56, 267-283.

Copper, C. L., \& Marshall, J. (1978). Sources of managerial and white-collar stress. In C. L. Copper, \& R. Payne (Eds.), Stress at Work (pp. 81-106). UK: Wiley.

Daniel, J. (1997). Zát’až, alebo stres? In L. Lovaš, \& J. Výrost (Eds.), Stratégie správania $v$ náročných životných situáciách (pp. 12-15). Košice: SÚ SAV.

Fedáková, D. (2002). Aktuálne prístupy k problematike stratégií správania v náročných situáciách. Človek a spoločnost', 5(3), 8-12.

Folkman, S., \& Lazarus, R. S. (1980). An analysis of coping in middle-aged community sample. Journal Health Social Behavior, 21, 219-239.

Folkman, S. et al. (1986). The dynamics of a stressful encounter: Cognitive appraisal, coping, and encounter outcomes. Journal of Personality and Social Psychology, 50, 992-1003.

Folkman S., \& Moskowitz J. T. (2004). Coping: Pitfalls and promise. Annual Review of Psychology, 55, 745-74.

Frankovský, M., \& Ištvániková, L. (2008). Management of the strategies of behavior in the demanding work situations. In R. Štefko, \& M. Frankovský (Eds.), Management 2008, Times of Global Chance and Uncertainty. Prešov: University of Prešov.

Frankovský, M., Ištvániková, L., \& Štefko, R. (2009). Strategies of behavior in demanding managerial work situations in social contexts. Studia psychologica 51(2-3,) 231-236.

Frankovský, M., \& Lajčin, D. (2012). Zvládanie náročných situácií v manažérskej praxi. Praha: RADIX.

Herrero, C., Egbu, C., \& Fong, D. (2018). Integrated model for the stressors, stress, stress-coping behaviour of construction project managers in the UK. International Journal of Managing Projects in Business, 11(3), 761-782. https://doi.org/10.1108/IJMPB-07-2017-0071

Ika, L., Couillard, J., \& Garon, S. (2021). Coping with project complexity: The complexity based project management framework. PM World Journal,10(5), 1-22.

Judge, T. A., Thoresen, C. J., \& Pucik, V. (1999). Managerial coping with organizational change: A dispositional perspective. Journal of Applied Psychology, 84(1), 107-122.

Kaulio, M., \& Uppvall, L. (2009). Critical incidents in R\&D alliances: Uncovering leadership roles. European Management Review, 6(3), 195-205.

Krahé, B. (1990). Situation cognition and coherence in personality. Cambridge: Cambridge University Press.

Krásna, S., Geršicová, Z., \& Tamášová, V. (2016). Vocational school teachers' job satisfaction in Slovakia. Karlsruhe, DE: Ste-con.

Lajčin, D., \& Frankovský, M. (2011). Zist’ovanie spôsobov zvládania náročných situácií $\mathrm{v}$ manažmente podniku. Journal of management and business: research and practice, 3(1), 93-104.

Lazarus, R. S. (1981). The stress and coping paradigma. In C. Eisdorfer et al. (Eds.), Models of clinical psychopathology (pp. 177-214). New York: Spektrum.

Lazarus, R. S., \& Folkman, S. (1984). Stress, appraisal, and coping. New York: Springer. 


\section{Acta Educationis Generalis \\ Volume 11, 2021, Issue 2}

Lazarus, R. S., \& Folkman, S. (1987). Transactional theory and research on emotions and coping. European Journal of Personality, 1, 141-170.

Lorincová, T., \& Birknerová, Z. (2019). Psychická zátaž a frustrogénne situácie u manažérov. Prešov: Bookman.

Madsen, S. M., \& Petermans, A. (2020). Designing retail - Unravelling coping strategies through emphatic interviewing owner managers. Journal of Retailing and Consumer Services, 55, 101884. https://doi.org/10.1016/j.jretconser.2019.101884

Mcnaughton-Cassill, M. E. (2015). Coping with stress. New York: Momentum Press.

Modranský, R., Bočková, K., \& Hanák, M. (2020). Project manager and stress in coping with demanding situations in automotive industry. Emerging Science Journal, 4(5), 418-426. https://doi.org/10.28991/esj-2020-01241

McCarthy, J. M., Erdogan, B., \& BAUER, N. T. (2019). An interpersonal perspective of perceived stress: Examining the prosocial coping response patterns of stressed managers. Journal of Organizational Behavior, 40(9/10), 1027-1044. https://doi.org/10.1002/job.2406

Mikšík, O. (1991). Osobnost’v náročných životných situáciách. Praha: Nadas.

Muhonen, T., \& Torkelson, E. (2008). Collective and individualistic coping with stress at work. Psychological Reports, 102(2), 450-458.

Nurmi, J. E., Toivonen, S., Salmela-Aro, K., \& Eronen, S. (1996). Optimistic, approach-oriented, and avoidance strategies in social situations: Three studies on loneliness and peer relationships. European Journal of Personality, 10, 201-219.

Oravcová, J. (2004). Sociálna psychológia. Zvolen: Bratia Sabovci.

Pitt, M., \& Sims, D. (1998). Preparing for novel situations: Evoking managerial role identities. Journal of Management Education, 22(6), 682-706.

Pujol-Cols, L., \& Lazzaro-Salazar, M. (2020). Psychological demands and health: An examination of the role of core self-evaluations in the stress-coping process. Psychological Studies, 65(4), 408-419. https://doi.org/10.1007/s12646-020-00569-5

Reese, H. W., \& Smyer, M. A. (1983). The dimensalisation of life events. In E. J. Callahan, \& K. A. McCluskey (Eds.), Lifespan Developmental Psychology. Nonnormative Life Events (pp. 1-33). New York: Acad. Press.

Reinert, E. (1999). The role of the state in economic growth. Journal of Economic Studies, 26 (4/5), 268-326.

Ronginska, T., \& Doliński, A. (2020). Strategies of coping with failure in the structure of managers' professional burnout syndrome. Management, 24(2), 94-106. https://doi.org/10.2478/manment-2019-0048

Rost, M., Sonnenmoser, E., \& Renzel, B. (2019). Social Networking: The crucial role of R\&D middle managers in facilitating ambidexterity and coping with digital transformation. Journal of Competences, Strategy, 10, 107-137. https://doi.org/0.978.395710/3390

Selye, H. (1956). The stress of life. McGraw-Hill.

Selye, H. (1966). Život a stres. Bratislava: SPN.

Sklenár. M., \& Frankovský, M. (2007). Rodovo a rodinne zodpovedná organizácia. Košice: Person.

Slaven, G., \& Flin, R. (1997). Selecting mangers for a hazardous environment. Disaster Prevention and Management, 6(5).

Střelka, J. (2008). Využití rozhodovacího rámce CYNFIN při řízení krizových situací. In Š. Hittmár et al. (Eds.), Aktuálne manažérske trendy v teórii a praxi. Žilina: EDIS.

Talbot, C. (1997). Paradoxes of management development - trends and tensions. Career development international, 2(3), 118-125.

Urban, J. (2008). Jak zvládnout 10 nejobtižnějšich situaci manažera. Praha: Grada.

Výrost, J. et al. (1995). Possibilities of empirical classifications of demanding life situations. Studia psychologica, 37, 93-106. 


\section{Acta Educationis Generalis \\ Volume 11, 2021, Issue 2}

Výrost, J. (1997). Náročné životné situácie, stratégie správania a ich vzt’ahy k príbuzným pojmom.

In L. Lovaš, \& J. Výrost (Eds.), Stratégie správania v náročných životných situáciách (pp. 611). Košice: SÚ SAV.

Yip, P. M., Goldman, A., \& Martin, A. L. (2021). Job satisfaction. University of Arizona. Retrieved from http://www.u.arizona.edu/ctaylor/chapter9/jobsat.html 